\title{
Implementation of Timber Legality Verification System for Forest Processed Wood Products Based on Ecological Justice
}

\author{
Sri Mulyani and Edy Lisdiyono*
}

Faculty of Law, Universitas 17 Agustus 1945, Semarang, Indonesia

\begin{abstract}
This study aims to analyze the application of the Timber Legality Verification System (SVLK) for forest processed wood products, namely furniture in Jepara Regency. SVLK is enforced to maintain harmony between environmental ecosystems and business ecosystems, this is in accordance with the concept of environmental justice which harmonizes environmental, economic and social in Jepara Regency. The research method used is normativeempirical (applied law research). The results showed that the importance of implementing SVLK on furniture in the Jepara Regency can increase the selling value in the global market and guarantee its legality. SVLK is regulated in the Regulation of the Minister of Forestry of the Republic of Indonesia Number: P.38/Menhut-II/2009 concerning Standards and Guidelines for Assessment of Performance of Sustainable Production Forest Management and Verification of Timber Legality in License Holders or in Private Forests. The implementation of SVLK in Jepara Regency for processed forest timber has not been optimal, because many IKMs do not yet have SLKs due to high costs and complicated procedures.
\end{abstract}

Keywords: Implementation, Forest Processed Timber, Ecological Justice, SVLK.

\section{INTRODUCTION}

Indonesia is a country rich in natural resources. This wealth should be an advantage that Indonesia has. Natural wealth can be maintained if the environment in it is well maintained. Talking about the environment, the most important thing is to maintain and care for the children and grandchildren to feel the benefits of the environment. The environment as a spatial unit with all objects, forces, conditions, including humans and other living creatures must be protected by its existence (Lisdiyono, 2018b).

Basically, the abundant natural resources in Indonesia are intended as a source of prosperity and welfare for the community. This is as regulated in the foundation of the Indonesian constitution as stated in Article 33 paragraph (3) of the 1945 Constitution of the Republic of Indonesia (UUD NRI 1945) which states that "The earth, and water and natural resources contained therein shall be controlled by the state and used for the greatest prosperity of the people."

One of the most excellent natural resource wealth is the wealth of forest resources. Forest according to Law Number 41 Year 1999 concerning Forestry explains that forest is an integrated ecosystem in the form of a stretch of land containing biological resources dominated by trees in their natural environment, which cannot be separated from one another. Forest describes the biophysical condition of the forest as a

*Address correspondence to this author at the Faculty of Law, Universitas 17 Agustus 1945, Semarang, Jl. Pawiyatan Luhur Bendan Dhuwur, Semarang, Central Java 50235, Indonesia; Tel: 024-8446280;

E-mail: edylisdi.untagsmg@gmail.com stretch of land overgrown with vegetation dominated by trees, and the ecological function of the forest as a community of plants in a single ecosystem capable of creating a microclimate (Puspitojati, 2011).

Abundant forest resources should be used for the welfare and prosperity of the people. Indonesia, which adheres to a welfare state, should balance the balance between nature and the people's welfare through the wealth of forest resources. As an effort to promote public welfare, the state has the authority to manage natural resources, in this case, forest resources for the welfare of the community (Hardiyanti \& Aminah, 2019).

Forest resources are one of the natural wealth commodities in Indonesia which still encounter problems in the implementation of their management to meet community needs, including the implementation of industry in the forestry sector. Some of the problems that still frequently occur in Indonesia include a large number of illegal logging and illegal trading which have resulted in the phenomenon of increasing deforestation in Indonesia. As a result, the quality of the ecosystem around the forest area has also deteriorated and has caused various phenomena of forest ecosystem damage.

Data from the Directorate General of Forestry Planning and Environmental Management (PTKL) of the Ministry of Environment and Forestry (KLHK), the results of monitoring Indonesian forests for 2019, show that the forest area of the entire mainland of Indonesia is 94.1 million ha or $50.1 \%$ of the total land area. Data from the Directorate General of PTKL also shows that Indonesia's deforestation trend is relatively lower and 
Table 1: Profile of the Jepara Regency Furniture Industry in 2020

\begin{tabular}{|c|c|c|c|c|}
\hline $\begin{array}{c}\text { Number of Small and Medium } \\
\text { Industries }\end{array}$ & Business Unit (Unit) & $\begin{array}{c}\text { Number of Workers } \\
\text { (people) }\end{array}$ & $\begin{array}{c}\text { Production Volume } \\
\text { (pieces/set) }\end{array}$ & $\begin{array}{c}\text { Production Value } \\
\text { (IDR) }\end{array}$ \\
\hline \hline Wood furniture & 5.870 & 75.603 & 4.098 .164 & 1.967 .139 .927 \\
\hline
\end{tabular}

Source: Jepara Regency in Figures in 2020.

tends to be stable. Net deforestation in 2018-2019, both inside and outside Indonesian forest areas, amounted to 462.4 thousand ha. This figure comes from a gross deforestation figure of 465.5 ha with a subtraction of the reforestation figure (results from satellite imagery monitoring) of 3.1 thousand ha. As a comparison, the results of Indonesian forest monitoring in 2018 show that the net deforestation in 2017-2018 both inside and outside the Indonesian forest area is 439.4 thousand ha, which comes from a gross deforestation figure of 493.3 thousand ha minus reforestation (monitoring results of satellite imagery) of 53.9 thousand ha. Taking into account the results of monitoring in 2018 and 2019, it can be seen that in net deforestation in Indonesia in 2018-2019 there was an increase of $5.2 \%$, however, for gross deforestation, there was a decrease of $5,6 \%$ (Kementerian Lingkungan Hidup dan Kehutanan, 2020)

Efforts to conserve forest resources have been regulated in several international and national regulations, including through the ratification of the Stockholm Conference which has been issued 3 (three) times related to the environment, namely, Law Number 4 of 1982 concerning Basic Provisions for Environmental Management (KPPLH), Law Number 23 the Year 1997 regarding Environmental Management (UUPLH), and Law Number 32 the Year 2009 concerning Environmental Protection and Management hereinafter abbreviated (UUPPLH) (Lisdiyono, 2018a)

Regulations for preserving forest resources have been regulated in Law Number 41 of 1999 concerning Forestry. Article 2 of Law Number 41 the Year 1999 concerning Forestry explains that the implementation of forestry is based on benefits and sustainability, society, justice, togetherness, openness and integration. Another regulation for preserving forests is the issuance of Law Number 32 of 2009 concerning Environmental Protection and Management.

The development of the business world, particularly the export of forest products in the era of globalization, demands legality. Indonesia applies the Timber Legality Verification System (SVLK) which is a new system in Indonesia with the main objective of reducing illegal logging and trade (Gultom et al., 2014). In global competition, the application of timber legality standards, especially processed timber with the SVLK (Timber Legality Verification System) system is a necessity. The legality of the SVLK is contained in the Regulation of the Minister of Trade of the Republic of Indonesia Number 38/M-DAG/PER/6/2017 concerning the Second Amendment to the Regulation of the Minister of Trade Number 84/M-DAG/PER/12/2016 concerning Provisions for Export of Forestry Industrial Products.

Based on the Regulation of the Minister of Trade, one of the affected areas in Indonesia is Jepara Regency. Jepara Regency is one of the regions in Indonesia which is the center for the wood processing industry (furniture). The furniture industry in the Jepara district is famous for its unique carvings, which is an intellectual property with local wisdom that has increased the added value of the furniture and wood handicraft industry products. Based on the 2020 Jepara Regency statistical report, there are 5,870 business units engaged in the furniture sector. The number of business units is able to absorb a workforce of 75,603 people (Badan Pusat Statistik Kabupaten Jepara, 2017). The following researchers present the industrial profile of Jepara Regency:

Based on the table above, it is clear that the implementation of Regulation of the Minister of Trade of the Republic of Indonesia Number 38/MDAG/PER/6/2017 concerning the Second Amendment to the Regulation of the Minister of Trade Number 84/M-DAG/PER/12/2016 concerning Provisions for Export of Forestry Industrial Products that Affects Small Industries Medium (IKM) in Jepara Regency. IKM complained that the cost was high, one of the obstacles in arranging SVLK by IKM because the procedure to obtain it was also complicated. Crafters are not familiar with the procedure (Kurniawan, 2015). On the one hand, SVLK has the advantage of providing legal protection and competitiveness for entrepreneurs of processed wood products on the free market, as well as providing legal protection for environmental conservation (Mulyani \& Lisdiyono, 2020). 
Based on research conducted by Yanto (2019), the impact of the SVLK implementation on the export of Indonesian forestry industry products, namely the recognition/acceptance of Indonesian products that are SVLK certified by importing countries can be seen in Indonesian export products to the European Union in the 2013-2016 period and Australia in the period 20142016 shows an increasing trend after the two countries entered into trade cooperation. The opposite condition occurs in the export of Indonesian forestry industry products to Japan and the United States, which have also implemented timber legality regulations. Indonesia's exports to these two countries show a downward trend, and even tend to be unstable for 3 years. It is suspected that this happened because the two countries had not entered into a cooperation agreement so that there was no mutual recognition/acceptance of the applied regulations. Based on this description, the researcher is interested in studying and analyzing the "Implementation of the Timber Legality Verification System for Processed Forest Timber Products based on Ecological Justice".

\section{FORMULATION OF THE PROBLEM}

Based on the above background, the writer can formulate the following problems:

1. Why is a timber legality verification standard needed for forest processed wood products in Jepara Regency?

2. How is the regulation of timber legality verification standards in Indonesia?

3. How is the implementation of timber legality verification standards for processed forest wood products based on ecological justice in the Jepara Regency?

\section{RESEARCH METHODS}

The research method is a way to solve problems or how to develop science using scientific methods (Efendi \& Ibrahim, 2018). The research method used is normative-empirical (applied law research) (Abdulkadir, 2004). The main point of study in empirical normative research is the implementation or implementation of positive legal provisions and contracts in fact on any particular legal event that occurs in society in order to achieve objectives.

This study uses prescriptive research, which is research that aims to provide an overview or formulate problems in accordance with existing circumstances or facts associated with existing standards/norms (Suteki \& Taufani, 2018). This study provides an overview of the implementation of the Timber Legality Verification System (SVLK) in the Jepara Regency which still causes injustice. When viewed from the regulation, SVLK has a good philosophy, namely protecting environmental sustainability and increasing the selling value of processed forest wood in foreign markets.

\section{DISCUSSION}

\section{The Urgency of Timber Legality Verification Standards for Forest Processed Timber Products in Jepara Regency}

Illegal logging has become an interesting issue to be discussed in various international meetings. Illegal logging is considered an extraordinary crime. Illegal logging has negative environmental, economic and social impacts (Nurkomariyah et al., 2016). One of the effects of illegal logging is the emergence of forest deforestation. Deforestation is defined as the loss or degradation of forest habitat caused by nature or humans. Degraded land and forest are defined as exforest land which is severely damaged because it is intensively and/or continuously disturbed, for example by forest fires or illegal logging of the damaged forest land which becomes less productive.

Jepara Regency which has a forest area of 13,975.93 hectares (Badan Pusat Statistik Provinsi Jawa Tengah, 2019). The forest area which is owned by Jepara Regency deserves to be guarded and preserved in order to sustain life in the future. Based on data from the Jepara Regency Environmental Service (DLH), in 2019 DLH recorded critical or barren land in Jepara as covering an area of 349.05 hectares. The data is outside the protected forest and plantation forest areas belonging to Perhutani (Shani, 2019).

Deforestation experienced by forests in Jepara District is not a coincidence. Jepara Regency is an area that has forest-processed wood products in the form of furniture or furniture. The high demands of the global market have caused entrepreneurs to compete to produce furniture or furniture. The data that the researchers obtained shows that in 2020 there were 5,870 business units engaged in the furniture sector with a production volume of $4,098,164$ pieces/set with total sales of IDR $1,967,139,927.00$. This data shows that the high demand for furniture or furniture products greatly affects forest deforestation in Jepara Regency. 
The government through the Ministry of Environment and Forestry in 2009 issued the Minister of Forestry Regulation Number: P.38/Menhut-II/2009 concerning Standards and Guidelines for Assessment of Sustainable Production Forest Management Performance and Verification of Timber Legality in License Holders or in Private Forests to tackle deforestation that continues in Indonesia. The regulation explains that in order to achieve Sustainable Production Forest Management (PHPL), as well as the implementation of forestry governance, the eradication of illegal logging and trade, it is necessary to stipulate Standard Guidelines for Performance Assessment of Sustainable Production Forest Management and Verification of Timber Legality in Permit Holders or Community Forests, Minister of Forestry Regulation (Suryandari et al., 2017).

Article 1 number $10 \quad$ P.38/Menhut-II/2009 concerning Standards and Guidelines for Assessment of Performance of Sustainable Production Forest Management and Verification of Timber Legality in License Holders or Private Forests states that the Standard Verification of Timber Legality (SVLK) is a requirement to fulfil timber legality/products made based on the agreement of the forestry stakeholders which contain standards, criteria, indicators, verifiers, verification methods, and assessment norms. The issuance of this regulation requires exporters to have V-Legal documents which are obtained from a system called the Timber Legality Verification System.

The Timber Legality Verification System (SVLK) is a multi-stakeholder tracking system to ensure the legality of timber sources circulating and trading in Indonesia. The Timber Legality Verification System (SVLK) was developed to encourage the implementation of applicable government regulations related to legal trade and circulation of forest products in Indonesia. A timber legality verification system is implemented in Indonesia to ensure that all wood products circulating and traded in Indonesia have a convincing legality status. Consumers abroad no longer need to doubt the legality of timber originating from Indonesia. The forest management unit is not worried that the legality of the timber is questioned. The wood-based industry believes in the legality of the source of its wood raw materials so that it is easier to convince overseas buyers (SILK, 2020).

In line with the issuance of a Regulation of the Minister of Environment and Forestry, the Ministry of Trade also issued a Regulation of the Minister of Trade of the Republic of Indonesia Number 84/MDAG/PER/12/2016 concerning Provisions for Export of Forestry Industrial Products which was promulgated on 27 December 2016. Based on this Regulation of the Minister of Trade explained that the Export of Forestry Products is limited by dividing the variation into two parts, namely Group A Forestry Industrial Products and Group B Forestry Industrial Products.

Group A forestry industry products consist of wood in the form of chips or pieces, wood chips, sawn timber, veener wood sheets, wooden furniture of a kind used in offices, wood furniture of a kind used in kitchens, wood furniture of a kind used in rooms bedding, furniture parts made of wood etc. according to attachment $A$ of the Regulation of the Minister of Trade of the Republic of Indonesia Number 84/M-DAG/PER/12/2016 concerning Provisions for Export of Forestry Industrial Products. Group B Forestry Industry Products consist of rattan lamps and curtains, baskets and rattan, rattan chairs, bedroom, dining room or family room made of rattan as in Attachment B of Regulation of the Minister of Trade of the Republic of Indonesia Number 84/MDAG/PER/12/2016 concerning Export Provisions for Forestry Industrial Products.

Based on Article 4 paragraph (1) states that the Export of Forestry Industrial Products as intended in Article 2 paragraph (2) which is included in group $A$ must be equipped with a $\mathrm{V}$-Legal Document issued by LVLK. Article 4 paragraph (2) states that the provisions as intended in paragraph (1) do not apply to group B, and Article 4 paragraph (3) states that the V-Legal Documents as intended in paragraph (1) are used as complementary customs documents that are required to Submission of export customs notification to the customs office.

The Timber Legality Verification System (SVLK) is very important in maintaining forest sustainability and adding to the selling value of processed wood products, in this case, furniture or furniture produced in Jepara Regency. SVLK provides forest sustainability because the existing SVLK process contains standards, criteria, indicators, verifiers, verification methods, and assessment norms that are agreed upon by stakeholders. SVLK also functions as SVLK to ensure wood products and their raw materials are obtained or derived from sources whose origin and management meet legality aspects. Timber is considered legal if the origin of the wood, the logging permit, the systems and procedures for cutting, transporting, processing, and trading or transferring it 
can be proven that it meets all applicable legal requirements. SVLK provides a selling value for forestprocessed wood products, in this case, furniture or furniture, because with the SVLK which legally guarantees timber legality, the timber export market can receive processed wood from Indonesian forest products. Processed wood from forest products can be valued with more economic value.

\section{Regulation of Timber Legality Verification Standards in Indonesia}

The Indonesian timber regime has been established since 1967 with the enactment of Law Number 5 concerning Basic Forestry Provisions. In this law, the discussion regarding the use of forest products for industrial purposes has been introduced in several regulations. In general, this regulation recognizes the potential of forest products as a commodity that can be utilized to achieve prosperity through its use in the industrial and export sectors (Basith, 2015).

Current regulations regarding forestry in Indonesia are regulated in Law Number 41 of 1999 concerning Forestry. Forestry management is based on benefits and sustainability, society, justice, togetherness, openness and integration. Forest administration is in line with the constitution, namely Article 33 paragraph (3) of the 1945 Constitution of the Republic of Indonesia (UUD NRI Year 1945) which states that "Earth, and water and natural resources contained therein are controlled by the state and used for the maximum the great prosperity of the people."

All forests within the territory of the Republic of Indonesia, including the natural resources contained therein, are controlled by the State for the maximum welfare of the people. Forest control by the State gives the Government the authority to regulate and manage everything related to forests and forest areas. Forest management is aimed at obtaining the maximum benefit as well as being versatile and sustainable for prosperity. Based on Article 21 of Law Number 41 the Year 1999 concerning Forestry, it is clear that forest management as referred to in Article 10 paragraph (2) letter $b$ includes the following activities:

a. Forest administration and preparation of forest management plans,

b. Forest utilization and forest area use,

c. Forest rehabilitation and reclamation,

d. Forest protection and nature conservation
Forest Protection and Management were further strengthened by the promulgation of Law Number 32 of 2004 concerning Environmental Protection and Management on October 3, 2009. Based on Article 15 paragraph (1) of Law Number 32 of 2004 concerning Environmental Protection and Management, it explains that The Government and Local Governments are required to make KLHS ensure that the principles of sustainable development have become the basis and are integrated into the development of an area and/or policies, plans, and/or programs. Jepara Regency, which is the Regional Government, is obliged to guarantee the principle of sustainable development by guaranteeing the legality of the production of traded forest processed wood.

Another regulation that underlies the existence of a Timber Legality Verification System, namely Law Number 18 of 2013 concerning the Prevention and Eradication of Forest Destruction. Prevention and eradication of forest destruction aim to ensure legal certainty and provide a deterrent effect for perpetrators of forest destruction, ensure the existence of forests in a sustainable manner while maintaining sustainability and not destroying the environment and surrounding ecosystems, optimizing the management and utilization of forest products by taking into account the balance of forest functions in order to create a prosperous society , and increasing the capacity and coordination of law enforcement officials and related parties in handling the prevention and eradication of forest destruction.

Indonesia, which is a welfare state, prioritizes the interests and welfare of its people. People's welfare must be in line with ecological justice, which prioritizes environmental, economic and social harmony. Indonesia through Law Number 3 of 2014 concerning Industry has the aim of realizing the national Industry as a pillar and driving force of the national economy; realizing the depth and strength of the Industrial structure; realizing an independent, competitive and advanced Industry as well as a Green Industry; realizing business certainty, fair competition, and preventing the centralization or control of Industry by one group or individual which is detrimental to society; open business opportunities and expand job opportunities; realizing equitable Industrial development throughout Indonesia in order to strengthen and strengthen national resilience, and increase the prosperity and welfare of society in an equitable manner. 
Table 2: Timber Legality Verification System Regulation

\begin{tabular}{|c|c|c|c|}
\hline No & Regulation & Article & Contents \\
\hline \multirow[t]{2}{*}{1} & \multirow{2}{*}{$\begin{array}{l}\text { Regulation of the Minister of Forestry of the } \\
\text { Republic of Indonesia Number: } \\
\text { P.38/Menhut-II/2009 concerning Standards } \\
\text { and Guidelines for Assessment of } \\
\text { Performance of Sustainable Production } \\
\text { Forest Management and Verification of } \\
\text { Timber Legality in License Holders or in } \\
\text { Private Forests }\end{array}$} & 2 paragraph (1) & $\begin{array}{c}\text { Performance assessment and timber legality verification of } \\
\text { IUPHHK, IPK, and IUIPHHK and Advanced IUI holders is } \\
\text { conducted by LP\&VI. }\end{array}$ \\
\hline & & 2 paragraph (2) & $\begin{array}{l}\text { Performance assessment of IUPHHK holders is carried out by } \\
\text { LP\&VI based on the Performance Assessment Standard for } \\
\text { Sustainable Production Forest Management (PHPL). }\end{array}$ \\
\hline \multirow[t]{3}{*}{2} & \multirow{3}{*}{$\begin{array}{l}\text { Permenhut Number: P.68/Menhut- II/2011 } \\
\text { concerning Amendments to Permenhut } \\
\text { Number P.38/Menhutll/2009 Concerning } \\
\text { Standards and Guidelines for Assessment } \\
\text { of Sustainable Production Forest } \\
\text { Management Performance and Verification } \\
\text { of Timber Legality in License Holders or in } \\
\text { Community Forests }\end{array}$} & 1 Number $12 \mathrm{~A}$ & $\begin{array}{l}\text { V-Legal sign is a sign affixed to timber, timber products or } \\
\text { packaging, which states that timber and wood products have } \\
\text { met PHPL or VLK Standards. }\end{array}$ \\
\hline & & 1 Number $14 \mathrm{~A}$ & $\begin{array}{l}\text { The Assessment Institute for Sustainable Production Forest } \\
\text { Management (LPPHPL) is an LP\&VI that is legally } \\
\text { incorporated in Indonesia, which assesses the performance of } \\
\text { sustainable production forest management (PHPL). }\end{array}$ \\
\hline & & 1 Number $14 \mathrm{~B}$ & $\begin{array}{c}\text { Timber Legality Verification Institute (LVLK) is an LP\&VI } \\
\text { incorporated in Indonesia that carries out timber legality } \\
\text { verification (LK). }\end{array}$ \\
\hline \multirow[t]{2}{*}{3} & \multirow{2}{*}{$\begin{array}{c}\text { Permenhut Number P.45/MenhutlI/2012 } \\
\text { Second Amendment to Permenhut Number } \\
\text { P.38/Menhut-II/2009 Concerning Standards } \\
\text { and Guidelines for Assessment of } \\
\text { Sustainable Production Forest Management } \\
\text { Performance and Verification of Timber } \\
\text { Legality in License Holders or in Community } \\
\text { Forests }\end{array}$} & 4 paragraph (6) & $\begin{array}{l}\text { S-LK as intended in paragraph (5) is valid for } 10 \text { (ten) years } \\
\text { from issuance and surveillance (surveillance) is carried out at } \\
\text { least once in } 24 \text { months. }\end{array}$ \\
\hline & & 7 paragraph (5) & $\begin{array}{c}\text { Holders of IUPHHK-HTR, IUPHHK-HKm, IUPHHK-HD, } \\
\text { IUIPHHK with a capacity of up to } 2,000 \mathrm{M} 3 \text { per year, TDI, IUI } \\
\text { with an investment capital of up to IDR } 500,000,000 .- \text { (five } \\
\text { hundred million rupiah) excluding land and buildings, including } \\
\text { home industries/craftsmen and export traders, may apply for } \\
\text { group certification of LK. }\end{array}$ \\
\hline 4 & $\begin{array}{l}\text { Permenhut Number P.42/MenhutlI/2013 } \\
\text { Third Amendment to Permenhut Number } \\
\text { P.38/Menhut-II/2009 Concerning Standards } \\
\text { and Guidelines for Assessment of } \\
\text { Performance in Sustainable Production } \\
\text { Forest Management and Verification of } \\
\text { Timber Legality in License Holders or in } \\
\text { Community Forests }\end{array}$ & 10 paragraph (6) & $\begin{array}{l}\text { LK certificate for IUI with an investment of up to IDR } \\
500,000,000 \text {.- (five hundred million rupiah) outside the land } \\
\text { and buildings, TDI and home industry/crafts and export } \\
\text { traders is valid for } 6 \text { (six) years from issuance and surveillance } \\
\text { is carried out at least- at least } 24 \text { months. }\end{array}$ \\
\hline \multirow[t]{3}{*}{5} & \multirow[t]{3}{*}{$\begin{array}{l}\text { Regulation of the Minister of Trade of the } \\
\text { Republic of Indonesia Number } 84 / \mathrm{M}- \\
\text { DAG/PER/12/201 } 6 \text { concerning Provisions } \\
\text { for Export of Forestry Industrial Products }\end{array}$} & 4 paragraph (1) & $\begin{array}{l}\text { Export of Forestry Industrial Products as intended in Article } 2 \\
\text { paragraph (2) included in group A must be equipped with a V- } \\
\text { Legal Document issued by LVLK. }\end{array}$ \\
\hline & & 4 paragraph (2) & $\begin{array}{l}\text { The provisions referred to in paragraph (1) do not apply to } \\
\text { group B }\end{array}$ \\
\hline & & 4 paragraph (3) & $\begin{array}{l}\text { (2) V-Legal documents as intended in paragraph (1) are used } \\
\text { as complementary customs documents which are required to } \\
\text { submit export customs notification to the customs office. }\end{array}$ \\
\hline
\end{tabular}


(Table 2). Continued.

\begin{tabular}{|c|c|c|c|}
\hline \multirow[t]{3}{*}{6} & \multirow{3}{*}{$\begin{array}{l}\text { Regulation of the Minister of Trade of the } \\
\text { Republic of Indonesia Number } 38 / \mathrm{M}- \\
\text { DAG/PER/6/2017 concerning the Second } \\
\text { Amendment to the Regulation of the } \\
\text { Minister of Trade Number } 84 / \mathrm{M}- \\
\text { DAG/PER/12/2016 concerning Provisions } \\
\text { for Export of Forestry Industrial Products }\end{array}$} & 8 paragraph (1) & $\begin{array}{c}\text { Forestry Industrial Products as intended in Article } 5 \text { paragraph } \\
\text { (1) can only be exported after Verification or Technical Tracing } \\
\text { has been carried out before loading the goods. }\end{array}$ \\
\hline & & 8 paragraph (2) & $\begin{array}{l}\text { (2) The Surveyor appointed by the Minister shall carry out the } \\
\text { Verification or Technical Tracing as intended in paragraph (1) }\end{array}$ \\
\hline & & 8 paragraph (6) & $\begin{array}{l}\text { LS as intended in paragraph (6) paragraph (5) must contain a } \\
\text { statement of truth on the results of Verification or Technical } \\
\text { Tracing and become the full responsibility of the Surveyor. }\end{array}$ \\
\hline \multirow[t]{2}{*}{8} & \multirow[t]{2}{*}{$\begin{array}{l}\text { Regulation of the Minister of Trade Number } \\
15 \text { of } 2020 \text { concerning Provisions for Export } \\
\text { of Forestry Industrial Products }\end{array}$} & 2 paragraph (2) & $\begin{array}{l}\text { Forestry Industrial Products as intended in paragraph (1) are } \\
\text { listed in Appendix I which is an integral part of this Ministerial } \\
\text { Regulation. }\end{array}$ \\
\hline & & 4 paragraph (1) & $\begin{array}{l}\text { Forestry Industrial Products as intended in Article } 2 \text { paragraph } \\
\text { (2) can only be exported after meeting the technical criteria as } \\
\text { listed in Attachment II which is an integral part of this } \\
\text { Ministerial Regulation. }\end{array}$ \\
\hline 9 & $\begin{array}{l}\text { Regulation of the Minister of Trade Number } \\
45 \text { of } 2020 \text { concerning Revocation of } \\
\text { Regulation of the Minister of Trade Number } \\
15 \text { of } 2020 \text { concerning Provisions for Export } \\
\text { of Forestry Industrial Products }\end{array}$ & 1 & $\begin{array}{l}\text { When this Ministerial Regulation comes into force, Regulation } \\
\text { of the Minister of Trade Number } 15 \text { of } 2020 \text { concerning } \\
\text { Provisions for Export of Forestry Industrial Products (State } \\
\text { Gazette of the Republic of Indonesia of } 2020 \text { Number 182), is } \\
\text { withdrawn and declared invalid. }\end{array}$ \\
\hline
\end{tabular}

Source: Extracted from Minister of Forestry Regulation and Minister of Trade Regulation.

Based on Article 7 of Law Number 3 of 2014 concerning Industry, it is explained that the Government, Provincial Government, and Regency/City Regional Government jointly or in accordance with their respective authorities carry out government affairs in the Industrial sector as regulated in this Law. Each Regent/Mayor prepares a Regency/City Industrial Development Plan. Regency/City Industrial Development Plans are prepared by referring to the Master Plan for National Industrial Development and National Industrial Policy. Regency/Municipal Industrial Development Plans are prepared with at least regard to the potential for regional Industrial resources; Provincial Spatial Planning (RT/RW) and Regency/City Spatial Layout Plans; as well as harmony and balance with socioeconomic activities and environmental carrying capacity.

Other regulations governing trade are the promulgation of Law Number 7 of 2014 concerning Trade. One of the policies, as stated in the law, is that trade must consider environmental perspectives. One of the arrangements for trading activities is designed to increase economic growth and increase natural resources. Based on this, the Government in the 20092013 periods, through the Ministry of Forestry has issued several legal bases regulating the Timber Legality Verification System (SVLK) (Susilawati, 2014). The form of technical regulations is contained in ministerial regulations, namely the Minister of Forestry Regulation and the Minister of Trade Regulation. The following is the researcher pouring out the ministerial regulations in the above table:

Based on the table above regarding the regulation of the Timber Legality Verification System (SVLK), it can be analyzed that the SVLK is technically regulated in the Minister of Forestry Regulation and the Regulation of the Minister of Trade. These regulations are interrelated in which the Minister of Forestry Regulation is the main pioneer in preserving the environment and the Regulation of the Minister of Trade as a pioneer in adding to the selling value of 
processed forest wood in the free market. Based on the table above, it can also be analyzed that the regulations governing SVLK are always changing due to economic factors, political factors, legal factors and legal culture.

Implementation of Timber Legality Verification Standards for Forest Processed Timber Products Based on Ecological Justice in Jepara Regency

The geographical position of Jepara Regency is located in the northern part of Central Java Province, with coordinates $110^{\circ} 9$ '48.02 "- $110^{\circ} 58^{\prime}$ '37.40" East Longitude and $5^{\circ} 43$ '20.67 "- $6^{\circ} 47^{\prime}$ 25.83" LS, with territorial boundaries covering West: Java Sea; North: Java Sea; East: Pati and Kudus Districts; and south: Demak Regency. The closest distance from the district capital is the Tahunan District which is $7 \mathrm{~km}$ and the farthest distance is the Karimunjawa District which is $90 \mathrm{~km}$. The area owned is $100,413,189$ hectares or around $1,004.13 \mathrm{~km}^{2}$, covering 16 Districts, 184 Villages and 11 sub-district. Meanwhile, the sea area is 2,112,836 $\quad \mathrm{km}^{2} \quad$ (https://jepara.go.id/profil/kondisigeografis/). Jepara Regency has a vision "Realizing a Jepara Madani with Character, Advanced and Competitive" and has the following mission (https://jepara.go.id/profil/visi-misi/):

1. Strengthening the Potential of Qualified, Religious and Cultured Human Resources

2. Balanced Utilization of Natural Resources for Community Welfare

3. Realizing a Progressive and Independent Regional Economy

\section{Realizing Equitable Development}

5. Improving good governance and professional public services

Jepara Regency is known as the center of the furniture industry. The furniture industry in Jepara Regency has special characteristics, namely carvings of carved patterns and motifs that are not easily imitated by producers from other cities and countries as well as their uniqueness and characteristics that show a strong local culture (Widiartanti, 2017). The furniture industry in Jepara Regency is mostly done by Small and Medium Industries (IKM). Based data from the Central Bureau of Statistics of Jepara Regency, it shows that there are as many as 5,870 business units in the District of Kedung, Pecangaan District,
Kalinyamatan District, Wagian District, Nalumsari District, Batealit District, Tahunan District, Jepara District, Mlonggo District. Most furniture IKMs are in the Annual District with 2,938 Business Units (Badan Pusat Statistik Kabupaten Jepara, 2020).

Furniture which is the prima donna for the people of Jepara Regency provides a very large economic contribution. Based on data from the Office of Industry and Trade in 2019, the nominal investment in furniture is valued at IDR $895,802,808,944$, this is the largest contribution to the Regional Original Income (PAD) of Jepara Regency (Diskominfo Kab.Jepara, 2020). The contribution and contribution of furniture to the PAD of Jepara Regency also has a negative impact on environmental conditions, especially the condition of the forests in Jepara Regency. Deforestation that continues to be experienced by the forest in Jepara Regency has caused instability in the environment and business ecosystems, both of which need each other and affect the welfare of the people in Jepara Regency.

The balance and harmony between environmental sustainability and business in the regulations have been stipulated through the Minister of Forestry and Trade Ministerial Regulations. Regulation of the Minister of Forestry of the Republic of Indonesia Number: P.38/Menhut-II/2009 concerning Standards and Guidelines for Assessment of Performance of Sustainable Production Forest Management and Verification of Timber Legality in Permit Holders or Private Forests which have undergone a process of the amendment until now in effect Permenhut Number P.42/Menhutll/2013 Third Amendment to Minister of Forestry Regulation Number P.38/Menhut-II/2009 concerning Standards and Guidelines for Assessment of Performance in Sustainable Production Forest Management and Verification of Timber Legality in License Holders or in Community Forests. Regulation of the Minister of Trade of the Republic of Indonesia Number: 84/M-DAG/PER/12/2016 concerning Provisions for Export of Forestry Industrial Products, which in the course of the last amendment in 2020 was issued a Regulation of the Minister of Trade Number 45 of 2020 concerning the Revocation of Regulation of the Minister of Trade Number: 15 of 2020 concerning Provisions for the Export of Forestry Industrial Products.

The regulations issued by the two ministers are in line with Law Number 41 of 199 concerning Forestry, Law Number 32 of 2009 concerning Environmental Protection and Management, Law Number 3 of 2014 
Table 3: Holder of Timber Legality Certificate in Jepara Regency

\begin{tabular}{|c|c|c|c|}
\hline No. & Company name & Address & No S-LK \\
\hline \hline 1 & A Amin Furniture & $\begin{array}{r}\text { Kedungcino Village, Rt.01, Rw.01, Jepara District, Jepara } \\
\text { Regency, Central Java Province }\end{array}$ & $54-S V L K-021$ \\
\hline 2 & Abad Jepara & Banjaran Village Rt. 01/01 Kec. Bangsri & CU83540SVLK-01-2017 \\
\hline 3 & Accent House & $\begin{array}{r}\text { Troso Village, Rt.005/Rw.008, Kec. Pecangaan, Kab. Jepara, } \\
\text { Prop. Central Java }\end{array}$ & VLK 00304 \\
\hline 4 & Adi Karya Utama & $\begin{array}{r}\text { Jl. Kh. Abdullah Faqih, Kecapi Village, Rt. 13/2, Annual District, } \\
\text { Jepara Regency, Central Java Province }\end{array}$ & $133.1 /$ EQC-VLK/IX/2017 \\
\hline 5 & Adjie Prima & Mambak Village Rt 01 Rw 04 Pakis Aji Jepara & LVLK-003/MUTU/LK-699 \\
\hline 6 & Agraprana Furniture & $\begin{array}{r}\text { Village Tahunan Rt. 002 Rw. 004, Tahunan Kab. Jepara, } \\
\text { Central Java }\end{array}$ & BRIK-VLK-0131 \\
\hline 7 & Ajisaka Baru & $\begin{array}{r}\text { Jl. Raya Bawu - Batealit, Rt.01/01, Ds. Bawu, Kec. Batealit, } \\
\text { Kab. Jepara, Prop. Central Java }\end{array}$ & \\
\hline
\end{tabular}

Source: extracted from WEB Timber Legality Information System.

concerning Industry, and Law Number 7 of the Year 2014 on Trade. Based on Article 2 paragraph (3) Permenhut Number P.42/Menhutll/2013 explains that the regulation, that verification of timber legality of holders of IUPHHK, IPK, IUIPHHK and Advanced IUI and Private Forest Owners (Hutan Rakyat) is carried out by LP\&VI based on the Legality Verification Standard. Wood (SVLK). The result of the SVLK is the issuance of $V$-Legal documents. The V-Legal document is a document that states that wood products for export purposes meet the timber legality verification standards in accordance with the provisions of the Government of the Republic of Indonesia. The V-Legal document is a very important document that must be owned by exporters. This V-Legal document is a complementary customs document that is required for submitting export customs notification to the customs office.

Jepara Regency is an autonomous region that is subject to and obedient to Law Number 23 Year 2010 concerning Regional Government. Based on Article 5 paragraph (4) it is explained that the Administration of Government Affairs as referred to in paragraph (2) in the Regions is carried out based on the principles of Decentralization, Deconcentration and Assistance Tasks. In forestry management, it is included in selected governmental affairs. (2) Government Affairs in the forestry sector as referred to in paragraph (1) relating to the management of regency/municipal forest park.

Based on the decentralization-based authority granted by Law Number 23 of 2014 concerning Regional Government, Jepara Regency issued Jepara Regency Regional Regulation Number 24 of 2011 concerning Management of Forest Resources with the Community of Jepara Regency. The regional regulation aims to accommodate and anticipate the development of community aspirations to obtain optimal benefits from forests and forest areas, so in principle, all forests and forest areas must be able to be utilized while still paying attention to their nature, characteristics and vulnerability, without changing their main functions. Another objective of the establishment of this regional regulation is also an effort to empower the community through the management of forest resources together with the community in the smallest management unit so that it can be managed effectively and sustainably in accordance with the function of the forest so that the main goal is to improve community empowerment and welfare from forest utilization efforts to succeed.

SVLK regulations are also found in Regional Regulation Number 2 of 2014 concerning the Protection, Empowerment and Development of the Furniture Industry. This regional regulation was formed because the furniture industry in Jepara Regency is the backbone of the regional economy and contributes significantly to the Gross Regional Domestic Product of the Jepara Regency, as well as being one of the national furniture industry centers which are widely known at the international level. Based on Article 12 paragraph (1) states that every furniture product exported must meet administrative requirements and quality standards. Administrative requirements and quality standards are regulated in a Regent Regulation, but empirically there is no such regulation.

In fact, the implementation of SVLK in Jepara District is not yet optimal. Based on the results of an interview with Ms. Ningsih as the owner of the IKM 


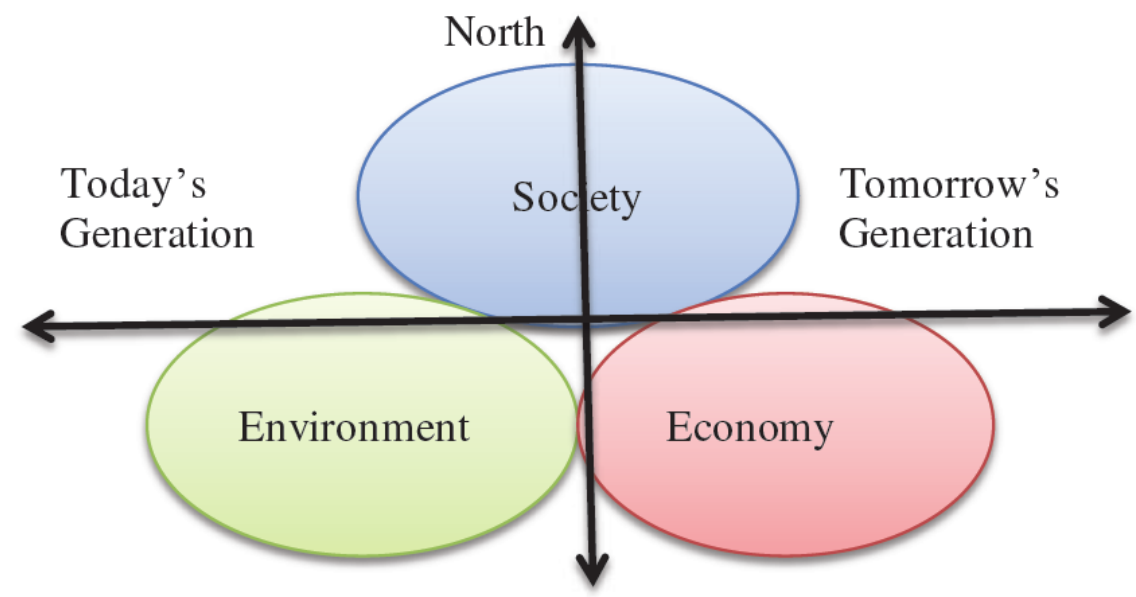

Figure 1: Three Dimensional Models.

Source: Stockholm Declaration (1972) towards Rio de Janeiro 1992 to Rio + 10 in Summit (2002) "Three Pillars of Sustainable Development".

"Wana Karya" stated that "many IKMs do not yet have a timber legality certificate issued by the timber legality verification agency, this is due to the high cost and complicated management due to the long procedure. IKM prefers to rent the quota (expedition) owned by the company to deposit the furniture that will be exported abroad. In line with what Mrs. Ningsih explained, IKM entrepreneur "Karomah Jati" owned by Mr. Siswanto also explained that "ignorance of SVLK management and high costs are the main reasons for IKM not having SVLK. Besides that, those who seek convenience by entrusting (expedition) for their furniture makes many IKMs do not have SVLK. Following are the authors present several companies holding Timber Legality Certificates (S-LK) in Jepara Regency:

Based on Table 3 above, it can be analyzed that those who get S-LK are all companies in the form of Limited Liability Companies (PT) while Small and Medium Industries (IKM) based on the results of research in the field do not have S-LK. The reason why IKM does not have S-LK is the high cost and complicated procedures. Research by Reza Ahda Sabiiila et al., (2018) also stated that the SVLK scheme is still constrained by the large cost of certification and the lack of knowledge about SVLK. The high costs incurred in obtaining a certificate are not yet in accordance with the expected price level (premium price). This condition is a disincentive for small and medium industries (IKM) and community forests (HR). The problems in implementing the SVLK are influenced by several things, including the inconsistency between demands for government regulations and conditions in the community which continue to be improved with policy improvements that are continuously being carried out by the government. All policies that are burdensome to business actors and cause high costs in management will discourage business actors from following the rules.

SVLK implementation should adhere to the principle of Ecological Justice. Ecological justice can be found in the 1972 Stockholm Declaration towards Rio de Janeiro 1992, up to Rio +10 in Johanesburg S. in 2002, which introduced the three pillars of development in all countries of the world. The three pillars emphasize the need for coordination and integration of natural resources, human resources, and artificial (economic) resources in every national development. The three pillars are known as the Three Dimensional Model. The Three Dimensional Model is described in the following diagram (Sugandhy \& Hakim, 2007):

The three pillars mentioned above are dimensions of integration and coordination between society, the economy and the environment. These pillars when implemented in SVLK are as follows:

\section{Society}

The Timber Legality Verification System (SVLK) is understood by the community as a pillar of human resources. Human resources have an important role in terms of organizing and regulating sustainability and harmony between the environment and the economy. The community must also play an active role in implementing SVLK in accordance with its objectives and uses so that a good culture of forest management will be formed for sustainable generations and business management for the sustainability of community welfare. 


\section{Environment}

The Timber Legality Verification System (SVLK) in the dimensions of the environmental pillar, namely the existence of the SVLK is expected to bring a change of thought towards forest sustainability, because this system requires legality of timber to be exported, thereby reducing the amount of illegal timber that is exported outside country and reduce excess deforestation in Jepara Regency.

\section{Economy}

The Timber Legality Verification System (SVLK) in the dimensions of the economic pillar, namely the existence of the SVLK, it is hoped that forest wood products that are processed into furniture will get high selling value in foreign markets. This is intended to increase the selling value so that there will be welfare for furniture craftsmen in Jepara Regency.

Based on the principle of Ecological Justice, it is hoped that the three pillars can create justice for now and for future generations. The principle of environmental justice is also expected to improve the welfare and justice for furniture craftsmen in Jepara Regency so that the goal of the country is to create the welfare of its people. For this reason, it is important and very urgent if the SVLK which applies in Indonesia is obliged to apply the principle of ecological justice.

\section{CONCLUSION}

Based on the results of research that has been carried out by researchers, it can be concluded that the SVLK needs to be optimized in Jepara Regency in order to sustain the environment and increase the selling value of furniture to be exported. The regulations regarding SVLK have been arranged coherently starting from Laws, Ministerial Regulations, to Regional Regulations, however, there is a need for socialization of these regulations to craftsmen because in fact there are too many rules which make it difficult for furniture craftsmen to understand SVLK. SVLK in its implementation in Jepara Regency has not been optimal, because of the complicated file management and the high cost of SVLK, many IKM do not have SLK.

\section{REFERENCES}

Abdulkadir, M. (2004). Hukum dan Penelitian Hukum. Bandung: PT. Citra Aditya Bakti.

Badan Pusat Statistik Kabupaten Jepara. (2017). Number of Business Unit (unit) and Manpower (people) According to The Type of Small and Midle Industry in Jepara Regency,
2015. Available: https://jeparakab.bps.go.id/statictable/ 2017/03/01/489/tabel-table-6-1-1-banyaknya-unit-usaha-unitdan-tenaga-kerja-orang-dirinci-menurut-jenis-industri-kecilmenengah-di-kabupaten-jepara-ikm-2015.html. Accessed 30 Sept 2020.

Badan Pusat Statistik Kabupaten Jepara. (2020). Banyaknya Sentra Industri Kecil di Kabupaten Jepara, 2018. Available: https://jeparakab.bps.go.id/statictable/2020/03/19/686/banya knya-sentra-industri-kecil-di-kabupaten-jepara-2018.html. Accessed 8 Oct 2020.

Badan Pusat Statistik Provinsi Jawa Tengah. (2019). Luas Penggunaan Lahan dan Luas Kawasan Hutan Menurut Kabupaten/Kota di Provinsi Jawa Tengah, 2018 (ha). Available: https://jateng.bps.go.id/statictable/2019/10/15/ 1745/luas-penggunaan-lahan-dan-luas-kawasan-hutanmenurut-kabupaten-kota-di-provinsi-jawa-tengah-2018-ha.html. Accessed 1 Oct 2020

Basith, A. A. (2015). Eropanisasi 'Eksternal'dalam Kebijakan Sistem Verifikasi Legalitas Kayu (SVLK) di Indonesia. Jurnal Hubungan Internasional, 4(2), 178-191. https://doi.org/10.18196/hi.2015.0078.179-191

Declaration, S. (1972). Declaration of the United Nations conference on the human environment. URL= http://www. unep. org/Documents. Multilingual/Default. asp.

Diskominfo Kab.Jepara. (2020). Data Industri Kecil dan Menengah Berdasarkan OSS Kabupaten Jepara Tahun 2019. Available: https://opendata.jepara.go.id/dataset/data-industri-kecil-danmenengah-berdasarkan-oss-kabupaten-jepara-tahun-2019. Accessed 8 Oct 2020

Efendi, J., \& Ibrahim, J. (2018). Metode Penelitian Hukum Normatif dan Empiris. Penerbit Pranadamedia Group, Jakarta.

Ferdy Kurniawan. (R-lisa FM Jepara, 2015). Dari 57 IKM Di Jepara Hanya 10 IKM Yang Ber-SVLK. Available: https://rlisafmjepara.com/2015/04/57-ikm-hanya-10-ikmyang-ber-svlk/. Accessed 30 Sept 2020.

Gultom, M., Astana, S., Effendy, R., \& Kurniawan, A. S. (2014). Sistem verifikasi legalitas kayu dan perbandingannya dengan sertifikasi sukarela pada level industri. Jurnal Analisis Kebijakan Kehutanan, 11(3), 261-275. https://doi.org/10.20886/jakk.2014.11.3.261-275

Hardiyanti, M., \& Aminah, A. (2019). Tinjauan Yuridis Terhadap Prinsip Pemberdayaan Masyarakat Dan Pembangunan Berkelanjutan Dalam Pengelolaan Sumber Daya Hutan Di Pulau Jawa. Bina Hukum Lingkungan, 4(1), 135-152. https://doi.org/10.24970/bhl.v4i1.92

Interview with Mr. Siswanto, Owner of IKM Karomah Jati, on October 7, 2020 in the Annual District of Jepara Regency

Interview with Mrs. Ningsih, Owner of IKM Wana Karya, on October 7, 2020 in the Annual District of Jepara Regency.

jepara.go.id. Kondisi Geografis. Available: https://jepara.go.id/profil/ kondisi-geografis/. Accessed 30 Sept 2020

jepara.go.id. Visi \& Misi. Available: https://jepara.go.id/profil/visi-misi/. Accessed 8 Oct 2020

Kementerian Lingkungan Hidup dan Kehutanan. (2020). Hutan dan Deforestasi Indonesia Tahun 2019. Available: http://ppid. menlhk.go.id/siaran_pers/browse/2435. Accessed 30 Sept 2020.

Lisdiyono, E. (2018a). Penerapan Azas Premium Remedium Dalam Perkara Pencemaran Lingkungan Hidup Akibat Limbah B3 Di Batam. Bina Hukum Lingkungan, 3(1), 1-12. https://doi.org/10.24970/jbhl.v3n1.1

Lisdiyono, E. (2018b). Penyelesaian Sengketa Lingkungan Hidup Haruskah Berdasarkan Tanggung Jawab Mutlak Atau Unsur Kesalahan. Jurnal Spektrum Hukum, 11(2).

Mulyani, S., \& Lisdiyono, E. (2020, May). Legal Protection Model for Forest Preservation of Processed Timber Businesses. In International Conference on Law, Economics and Health (ICLEH 2020) (pp. 580-583). Atlantis Press. https://doi.org/10.2991/aebmr.k.200513.112 
Nurkomariyah, S., Firdaus, M., \& Nurrochmat, D. R. (2016). Transformasi Regulasi Sertifikasi Legalitas Kayu. Risalah Kebijakan Pertanian Dan Lingkungan: Rumusan Kajian Strategis Bidang Pertanian dan Lingkungan, 3(3), 262-272. https://doi.org/10.20957/jkebijakan.v3i3.17250

Puspitojati, T. (2011). Persoalan definisi hutan dan hasil hutan dalam hubungannya dengan pengembangan HHBK melalui hutan tanaman. Jurnal Analisis Kebijakan Kehutanan, 8(3), 210227.

https://doi.org/10.20886/jakk.2011.8.3.210-227

Rhobi Shani. (medcom.id, 2019). 349 Hektare Lahan di Jepara Dinyatakan Kritis. Available: https://www.medcom.id/ nasional/daerah/ybJVgwWb-349-hektare-lahan-di-jeparadinyatakan-kritis. Accessed 2 Oct 2020.

Sabiila, R. A., Cahyadi, E. R., \& Hardjomidjojo, H. (2018). Kesiapan Industri Rumah Tangga Mebel terhadap Penerapan Sistem Verifikasi Legalitas Kayu di Yogyakarta. Jurnal Manajemen dan Organisasi, 9(1), 45-58.

https://doi.org/10.29244/jmo.v1i1.25369

Sistem Informasi Legalitas Kayu (SILK). (2020). Apa dan Bagaimana SVLK. Available: http://silk.dephut.go.id/index.php/info/ vsvlk/3. Accessed 30 Sept 2020.

Sugandhy, A., \& Hakim, R. (2007). Prinsip dasar kebijakan pembangunan berkelanjutan berwawasan lingkungan. Bumi Aksara.
Summit, J. (2002). Johanesburg Summit-Secretary General calls for global action on water issues.

Suryandari, E. Y., Djaenudin, D., Astana, S., \& Alviya, I. (2017). Dampak implementasi sertifikasi verifikasi legalitas kayu terhadap keberlanjutan industri kayu dan hutan rakyat. Jurnal Penelitian Sosial dan Ekonomi Kehutanan, 14(1), 19-37. https://doi.org/10.20886/jpsek.2017.14.1.19-37

Susilawati D. (2014). Evaluasi Sistem Verivikasi Legalitas Kayu (SVLK) dan Praktek Lokal di Hutan Rakyat. Available: https://arupa.or.id/sources/uploads/2014/05/SVLK-di-HutanRakyat.pdf. Accessed 24 Sept 2020.

Suteki \& Taufani, G. (2018). Metodologi Penelitian Hukum (Filsafat, Teori Dan Praktik). Depok: PT RajaGrafindo Persada.

Widiartanti, F. (2017). Mebel Ukir Jepara dalam Menghadapi Kompetisi Perdagangan Global: Analisis Upgrading dalam Global Value Chain. Sospol: Jurnal Sosial Politik, 2(1), 56-70. https://doi.org/10.22219/sospol.v2i1.4755

Yanto, Y. (2019). Dampak Implementasi Regulasi Tentang Sistem Verifikasi Legalitas Kayu (SVLK) terhadap Ekspor Produk Industri Kehutanan Indonesia. Journal Penelitian Kehutanan FALOAK, 3(2), 101-116.

https://doi.org/10.20886/jpkf.2019.3.2.101-116

Received on 16-03-2021

https://doi.org/10.6000/1929-4409.2021.10.122

(C) 2021 Mulyani and Lisdiyono; Licensee Lifescience Global.

This is an open access article licensed under the terms of the Creative Commons Attribution Non-Commercial License (http://creativecommons.org/licenses/by-nc/3.0/) which permits unrestricted, non-commercial use, distribution and reproduction in any medium, provided the work is properly cited. 